\title{
Role of Governmental and Non-Governmental Agencies towards Disaster Risk Reduction in Rivers State, Nigeria
}

\author{
Collins H. Wizor (Ph.D) ${ }^{1 *}$, Cookey, Aloma Tammy (Ph.D) ${ }^{2}$ \\ ${ }^{I}$ Department of Geography and Environmental Management, University of Port Harcourt, P.M.B 5323, Port \\ Harcourt, Nigeria. \\ ${ }^{2}$ Department of Geography and Natural Resources Management, University of Uyo, Uyo, Nigeria.
}

*Corresponding Author: Collins H. Wizor (Ph.D), Department of Geography and Environmental Management, University of Port Harcourt, P.M.B 5323, Port Harcourt, Nigeria

\begin{abstract}
This study looked at the role of governmental and non-governmental agencies towards disaster risk reduction in Rivers State, Nigeria with the view to ascertain if disaster Risk Reduction activities have contributed to meaningful development in the study area.Data for the study was collected through questionnaire survey and interviews while population for the study was 715 respondents which included (youths, women and men) from selected communities in Ahoada West and Ogba/Egbema/Ndoni LGAs of Rivers State, Nigeria. Given the nature of the research and efficacy of the study, five officials from Total E\&P Emergency Response Team and Shell Emergency Response Team who are under non-governmental Agencies were interviewed while officials from National Emergency Management Agency (NEMA) and Rivers State Ministry of Special Duties representing the governmental Agencies were also interviewed. Results of the study shows that the most prevalent disasters in the study areaare flooding (AWELGA) and Oil spillage (ONELGA). Majority of the respondents from the Agencies that carry out DRR activities and those residing in the communities where DRR is being carried out in both local government areas had their opinion that DRR activities have led to a remarkable sustainable development. The results further revealed that, adequate funding, partnership, training and retraining of staff are the major factors that have led to the success of DRR activities and sustainable development with adequate funding taking topmost priority. It was recommended that officials of governmental and non-governmental Agencies involved in DRR activities should be well trained in line with global standard; the administration of DRR policies should be better supported financially for effective monitoring and enforcement of DRR laws. The study concluded that DRR policies should embrace inputs from indigenous people in terms of participation and consultation to help in the implementation process especially in the area of monitoring for compliance. Community or public awareness campaign was strongly advocated as a means of information by the government and non-governmental Agencies to disaster prone communities while a more robust and all-inclusive partnership and collaboration with other stakeholders involved in DRR activities across the globe was suggested in order to ensure compliance with global best practices in the country.
\end{abstract}

Keywords: Disaster; Risk Reduction; Governmental Agencies; Non-GovernmentalAgencies; Sustainable Development

\section{INTRODUCTION}

Globally, the impact of disasters has risen rapidly over recent decades affecting almost all sectors and rich countries and poor countries alike. Several hundred million people are affected annually and losses reached a record US\$ 371 billion in 2011(Annual Disaster Statistical Review, 2012). This figure may underreport the true losses by $50 \%$ or more. It does not incorporate knock-on impacts across economies and it undervalues the relative economic impacts on individual and particularly poor households. In some regions numerous smaller-scale and unreported events are a major source of aggregate loss, especially in developing countries and poor communities. A particular concern is that disaster-damaged livelihoods and economies can set the preconditions for further rounds of excessive exposure, susceptibility and loss, blocked escapes from poverty and negative spirals of development failure. This may occur at any level, from household to state (Annual Disaster Statistical Review, 2012). 
Role of Governmental and Non-Governmental Agencies towards Disaster Risk Reduction in Rivers State, Nigeria

The United Nations-sponsored Hyogo Framework for Action 2005-2015, which seeks to build the resilience of nations and communities to disasters, includes the integration of disaster risk considerations into sustainable development processes as a key strategy. One of its five priorities is the reduction of underlying risk factors, involving environmental, social and economic actions, but it is here that least progress has been achieved. Explicit recognition of disaster risk reduction in the Sustainable Development Goals (SDGs) will provide critical weight to help drive the substantive work on underlying disaster risk in the parallel post-2015 framework planned to succeed the Hyogo Framework for Action (UN/ISDR, 2009).

At the turn of the new millennium, Africa is a continent characterized by declining per capita income, increasing hunger, worsening ecological degradation and increasing global marginalization. As at 2003, about 40 million Africans faced the threat of starvation while nearly 200 million live with chronic hunger caused in part by disasters from natural hazards, HIV/AIDS and failed development. In response, Africa and its partners have re-invigorated efforts to address this malaise within the context of international development frameworks and commitments. (World Food Programme, 2003).

The United Nations and the international community have set targets for global sustainable development and poverty reduction under Agenda 21 of the Millennium Declaration. Progress in reducing vulnerabilities to disasters is essential for achieving the goals set by the above Declaration, goals known as Millennium Development Goals (MDGs). In turn, attaining the MDGs is crucial for reducing vulnerability to disasters. To achieve the Agenda 21 objectives, the Plan of Implementation of the Johannesburg 2002 World Summit on Sustainable Development (WSSD) called for mainstreaming disaster risk management in sustainable development. With specific regard to Africa; Section 8 of the Johannesburg Plan urged actions at all levels to assist Africa to deal effectively with natural disasters and conflicts, including their environmental and humanitarian impacts within the framework of the New Partnership for Africa's Development (NEPAD), (UN/ISDR \& UNDP 2003).

Disasters have increased in number over the past century from under 100 natural disasters reported annually before 1975 to over 450 disasters reported in 2000. This only takes into account natural disasters and is partly a factor of better reporting over time. However, population increase, increased urbanization, building in more risk prone areas, and climate change are all contributing to the increased number of disasters. Depending on an affected household's vulnerability and the systems put in place to protect these populations, hazards can quickly cause a household to spiral down into new levels of destitution (Boudreau, 2009). Overall, a greater proportion of the population - double what it was the previous decade - is now exposed to hazards, transforming hazards into disasters (DFID, 2006).

Disaster risk is a global concern, but not all areas or populations experience an equal threat from hazards. Disasters are highly concentrated in poorer countries like sub-Saharan Africa with weaker governance, in low and low-middle income countries with rapid economic growth, and where the exposure of people and assets is growing faster than risk-reducing capacities are being strengthened (Twiggs, 2007). The poor are particularly vulnerable to disasters given their already low income and depleted asset base, and therefore can ill afford to suffer increasing unemployment, crop and livestock losses, and lower wages or higher prices, especially on food items.

Disaster Risk Reduction (DRR) in this study describes a conceptual framework of elements considered with the possibilities to minimize vulnerabilities and disaster risk throughout a society and also avoid (prevention) or to limit (mitigation and preparedness) the adverse impact of hazards within the broad context of sustainable development. The rationale behind the role of institution in DRR is aimed at understanding its activities and impact with a view to produce a longer-term prevention and disaster losses; these involves hazard minimization (where possible) reducing exposure and susceptibility and enhancing coping and adaptive capacity. DRR is a new paradigm in disaster management with a body of policies, strategies and practices geared towards curtailing vulnerabilities and disaster risk in a society through appropriate prevention, mitigation, preparedness and early warning programs and activities.

Indeed, the crucial role of institutions in disaster risk reduction activities cannot be overemphasized. Information gathered showed that various stakeholders, both governmental and non-governmental institution are involved in DRR activities. 
Role of Governmental and Non-Governmental Agencies towards Disaster Risk Reduction in Rivers State, Nigeria

Disaster is linked to sustainable development and poverty in several ways. First, poverty reflects a negative development context wherein people's livelihood assets are eroded and their development capacity weakened to the extent that their resilience to disaster risks is undermined. Therefore, poverty and disasters are inter-linked development issues because the underlying causes of both are inter-related through basic common factors that promote or constrain development and livelihoods.

Secondly, the vulnerability factors expose people not only to natural hazards but also to risks from other sources of development and livelihood threats such as ill health, income variability, low access to productive assets and social services, and social disorder. Hence, the poor, who are most vulnerable to natural and related hazards, are also susceptible to other threats on their livelihoods, partly because disaster risks and other development risks and threats on livelihood mutually reinforce each other. For example, crop loss caused by drought can interact with falling income from the use of lowproductivity technology to cause disastrous reduction in agricultural incomes and induce famine. This complementarity of livelihood and disaster risks places additional burden on the livelihoods and coping mechanisms of the poor.

Other examples of failed development patterns include rapid urbanization that exacerbate disaster risks among the poor and the marginalized (UNEP, 2002), and over-centralized development management that contributes to low development and social exclusion (Batchelor, Smith and Fleming, 2014). Many development schemes are not adopted because they are not responsive to the circumstances of intended beneficiaries (Donovan and Casey, 1998). Failed development contributes to poverty because development objectives will not be achieved and disaster risk remains high as disaster reduction interventions also fail. Thus, effective disaster risk management requires tackling disasters within a development context.

However, development processes can contribute to reduction of disaster risk through interventions that enhance resilience, reduce poverty and provide buffers to vulnerability. Examples in Africa include efforts to provide social services, promote suitable agricultural and other technologies, develop risk management mechanisms, enhance decentralization and participatory development, and provide safety nets for the disadvantaged.

Previous studies have shown that effective DRR ensures sustainable development but in turn, sustainable development strengthens the security of populations so that disaster reduction interventions can effectively help them to alleviate or avoid disaster risks to themselves, their livelihoods and the supporting physical, economic and social base. This mutually beneficial situation occurs when development processes and patterns adequately address threats from disasters and other livelihood risks.

The negative effects of disasters on development and the close links between disasters and development imply that disaster losses need to be addressed in a development context. The growing trend of disasters in Nigeria has implications for national sustainability. This is because, disasters, irrespective of causal factors are associated with diverse externalities such as mortalities, loss of income, home, farmlands, social networks, livelihoods and infrastructures. The accelerating pace of urbanization and the growing scale of urban-industrial activity is exacerbating environmental stresses in developing-country cities and increasing the vulnerability of urban dwellers to both natural, technological and other human induced disasters (Kreimer and Munasinghe, 1991). The demand for more urban space has pushed the poor into marginal, environmentally vulnerable terrain. In many developing countries, overcrowding, congestion, poverty, unemployment, and inadequate infrastructure and services further weaken urban resistance to natural hazards (Munasinghe, 2016). All things considered; the long-term effects of disasters seriously affect countries' prospects for development.

In Nigeria, the following are the primary and secondary disaster response agencies: Nigeria Police Force (NPF),Federal Fire Service (FFS), Federal Road Safety Corps (FRSC), Nigeria Security and Civil Defense Corps (NSCDC), Nigerian Red Cross Society (NRSC), National Emergency Management Agency (NEMA), Nigerian Airspace Management Agency (NAMA), Nigeria Maritime and Safety Administration (NIMASA), Nigerian Inland Water Ways (NIWW),Directorate of Road 
Role of Governmental and Non-Governmental Agencies towards Disaster Risk Reduction in Rivers State, Nigeria

Transport Services (DRTS/VIOs), Private Construction Companies, International Development Partners (NGOs), Federal/State Ministry of Health (FMOH), Federal/ State Ministry of Environment (FMEnv), Federal/State Ministry of Works (FMOW), Federal Roads Maintenance Agency (FERMA), Federal Ministry of Transport (FMOT), Federal Ministry of Aviation (FMOAvi), Federal Airport Authority of Nigeria (FAAN), Nigerian Immigration Service (NIS), Nigerian Customs Service (NCS), Nigerian Prison Service (NPS), Accident Investigation Bureau (AIB) and Military (Army, Navy, Air Force).

The above institutions play key role in the operation of the different phase of DRM framework and mediating the link between development, DRM and humanitarian actions. Without institution, there would be no action and DRM would remain a concept on paper.For example during the mitigation/prevention phase, a variety of institutional actors including the public sector, technical ministries and agencies (e.g. agriculture,forestry, fisheries, health, education,local government ) international organizations, professional bodies, NGOs and other civil society organizations operate important programmes to build livelihood assets, improve household production, incomes and enhance resilience and coping strategies. In the relief stage for instance, these various organizations focus on "save and rescue" operations, meeting basic needs such as shelter, food and water. In the rehabilitation stage, their aim is to prevent further erosion of productive asset or coping strategies and to help household re-establish their livelihood.

\section{Materials AND Methods}

Ahoada West and Ogba/Egbema/Ndoni Local Government Areas (LGAs) of Rivers State occupy an area of about 704 square kilometres and 1,621 square kilometres respectively. They lie between latitude $4040^{\prime} 38^{`}$ North and longitude $6025^{\circ} 42^{`}$ East and are located North-West of Rivers State, bounded on the north by Ogbaru LGA of Anambra State; on the north-east by Oguta and Ohaji/Egbema LGAs of Imo State; on the west by Sagbama/Yenagoa LGAs of Bayelsa State and Ndokwa-East LGA of Delta State; on the south by Abua/Odua and Emohua LGAs and Ahoada East LGA of Rivers State (Rivers State ministry of information, 2006).

The area is located on the eastern bank of the River Niger and in the heart of the Niger Delta Region. The topography of this area is flat plain netted in a web of rivers -the Niger Sombeiro (Nkisa), Orashi and their tributaries as well as dotted creeks-Idia, Omoku. Onita,Utuegwe,Utuah,Ndoni,Igburu,etc, (Rivers State Ministry of Information, 2006).

The topography of this area in Rivers State is the freshwater zone of which the plain extends north ward from the mangrove swamps. This land surface is generally under $20 \mathrm{~m}$ above sea level. Most water channels in the fresh water zone is bordered by natural levees, which are of great topographical interest and of great economic importance to the people for settlement and crop cultivation. (Rivers State Ministry of Information, 2006). The major soil types are brown loams and sandy loams, sedimentary in nature. The soils are organic; some consist of mud mixed with decayed organic matter. The vegetation type recognizable within these LGAs is the rainforest because it is located in both wetland and upland area of Rivers State.

Ahoada West has twelve (12) wards namely Akinima, Ebiriba, Emezi, Iduekpeye, Joinkraima, Mbiama, Bodiereke,Odioku, Okarki, Okogbe, Ubeta, Upatabo, while ONELGA has seventeen (17) wards under six administrative zones namely, Omoku, Egbema, Ndoni, Egi, Usomini and Igburu. ONELGA and Ahoada West have an estimated population of 283,294 and 249,322 (NPC,2006 projected population). It is pertinent to add that both LGAs have a total of one hundred communities (National Bureau of Statistics, 2010). The presence of good climate, topography, vast arable land and vegetation and fertile soil make the people predominantly farmers, fishermen and few traders to balance her economy. The study area is blessed with abundant natural resources-oil and Gas. The area is the heart of the hydrocarbons industry and contributes the highest chunk feeder of natural gas to Nigeria Liquefied Natural Gas Project resulting in Nigeria's foreign earning (Rivers State Ministry of Information, 2006). 
Role of Governmental and Non-Governmental Agencies towards Disaster Risk Reduction in Rivers State, Nigeria

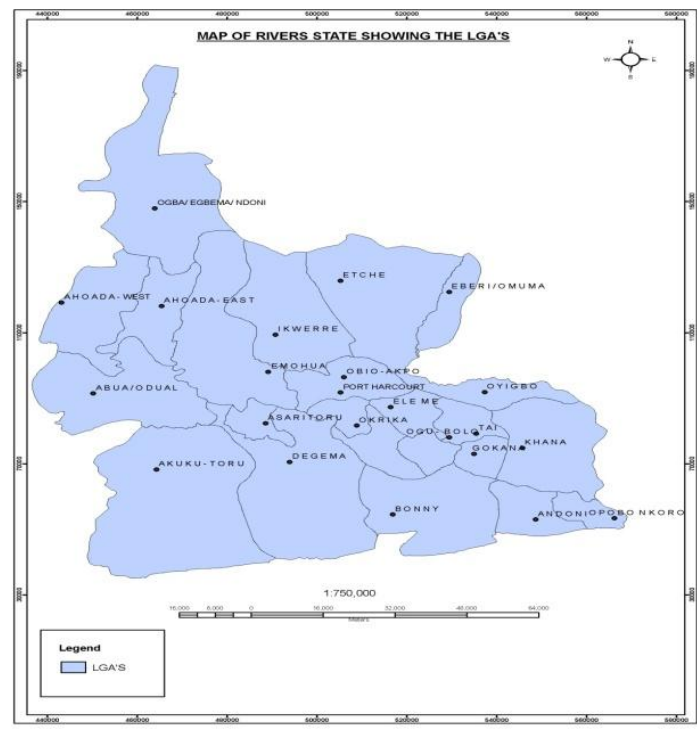

Figure1. Rivers State Showing LGAs

Source. Rivers State Lands and Survey, 2018

The data for this study was collected through questionnaire survey and interviews. The population for the study is 715 respondents which include (youths, women and men) from selected communities in Ahoada West which is grouped politically into two zones and Ogba/Egbema/Ndoni LGAs which is grouped politically into three zones; representing 30\% of the total communities in these Local Government Areas. There are one hundred (100) communities in both LGAs of which thirty (30) communities were purposively selected (these are communities where various Agencies are fully involved in DRR). See Figure 2 and 3 below.

Given the nature of the research, five officials from Total E\&P Emergency Response Team and Shell Emergency Response Team who are under non-governmental Agencies were interviewed. Officials from National Emergency Management Agency (NEMA, South SouthZonal Office) and Rivers State Ministry of Special Duties who are the governmentalAgencies and the enforcer of disaster/emergencies laws, policies and standard are among the respondents interviewed.

The questionnaire was distributed on household basis randomly in 30 disaster prone communities in both LGAs. However, for the purpose of analysis, only 574 questionnaireswere retrieved in the two LGAs (See table 1 below).

Table1. Questionnaire Distribution to 30 Host Communities

\begin{tabular}{|c|c|c|c|c|c|}
\hline$L G A$ & Zones & $\begin{array}{l}\text { Names of selected } \\
\text { communities }\end{array}$ & $\begin{array}{l}\text { No of } \\
\text { Household } \\
\text { (estimated) }\end{array}$ & Respondents & $\begin{array}{l}\text { No of questionnaire } \\
\text { retrieved }\end{array}$ \\
\hline $\begin{array}{l}\text { Ahoada } \\
\text { West }\end{array}$ & Ekpeye & $\begin{array}{l}\text { 1.Idu } \\
\text { 2. Oyigbo } \\
\text { 3.Ubeta } \\
\text { 4.Ulo } \\
\text { 5.Odieke } \\
\text { 6.Ogbologbolo } \\
\end{array}$ & $\begin{array}{l}261 \\
196 \\
281 \\
122 \\
100 \\
187 \\
\end{array}$ & $\begin{array}{l}26 \\
20 \\
28 \\
12 \\
10 \\
19\end{array}$ & $\begin{array}{l}24 \\
19 \\
20 \\
12 \\
10 \\
17\end{array}$ \\
\hline & Engenni & $\begin{array}{l}\text { 1.Oshi } \\
\text { 2.Betterland } \\
\text { 3.Ususu JK } \\
\text { 4.Kanusha }\end{array}$ & $\begin{array}{l}57 \\
42 \\
354 \\
109 \\
\end{array}$ & $\begin{array}{l}7 \\
4 \\
35 \\
11\end{array}$ & $\begin{array}{l}6 \\
4 \\
28 \\
9 \\
\end{array}$ \\
\hline ONELGA & $O g b a$ & $\begin{array}{l}\text { 1.Obrikom } \\
\text { 2.Erema } \\
\text { 3.Ibewa } \\
\text { 4.Idu } \\
\text { 5.Obagi } \\
\text { 6.Ogbogu } \\
\text { 7.Egbegboro }\end{array}$ & $\begin{array}{l}441 \\
560 \\
140 \\
268 \\
261 \\
476 \\
69\end{array}$ & $\begin{array}{l}44 \\
56 \\
14 \\
27 \\
26 \\
48 \\
7\end{array}$ & $\begin{array}{l}32 \\
48 \\
12 \\
20 \\
23 \\
43 \\
7\end{array}$ \\
\hline
\end{tabular}


Role of Governmental and Non-Governmental Agencies towards Disaster Risk Reduction in Rivers State, Nigeria

\begin{tabular}{|c|c|c|c|c|c|}
\hline & & 8.Itu & 41 & 4 & 4 \\
\hline & Egbema & $\begin{array}{l}\text { 1.Agah } \\
\text { 2.Ebocha } \\
\text { 3.Mgbede } \\
\text { 4.Okwuzi } \\
\text { 5.UgadaUkwu } \\
\text { 6.Ekpe }\end{array}$ & $\begin{array}{l}513 \\
250 \\
501 \\
191 \\
555 \\
130\end{array}$ & $\begin{array}{l}52 \\
25 \\
50 \\
19 \\
55 \\
13\end{array}$ & $\begin{array}{l}41 \\
20 \\
27 \\
18 \\
33 \\
5\end{array}$ \\
\hline & Ndoni & $\begin{array}{l}\text { 1.Ndoni } \\
\text { 2.Isukwa } \\
\text { 3.Abada Ukwu } \\
\text { 4.Ogbogene } \\
\text { 5.Obiafu } \\
\text { 6.Utu }\end{array}$ & $\begin{array}{l}469 \\
63 \\
63 \\
186 \\
141 \\
122 \\
\end{array}$ & $\begin{array}{l}46 \\
6 \\
6 \\
19 \\
14 \\
12 \\
\end{array}$ & $\begin{array}{l}38 \\
6 \\
6 \\
18 \\
14 \\
10 \\
\end{array}$ \\
\hline TOTAL & & & 7150 & 715 & 574 \\
\hline
\end{tabular}

Source. Authors Analysis, 2018.

The results of the analysis are presented with the aid of appropriate maps, tables, textual and graphic representations. In addition, the hypothesis was tested using the Spearman Rank Order Correlation and was analyzed using the Statistical Package for Social Science (SPSS) version 20. Also, Z Test Analysis and Degrees of Freedom (df) were used since it has to do with testing statistically significant difference in the level of the role of government and Non-governmental Agencies in DRR activities and sustainable development.

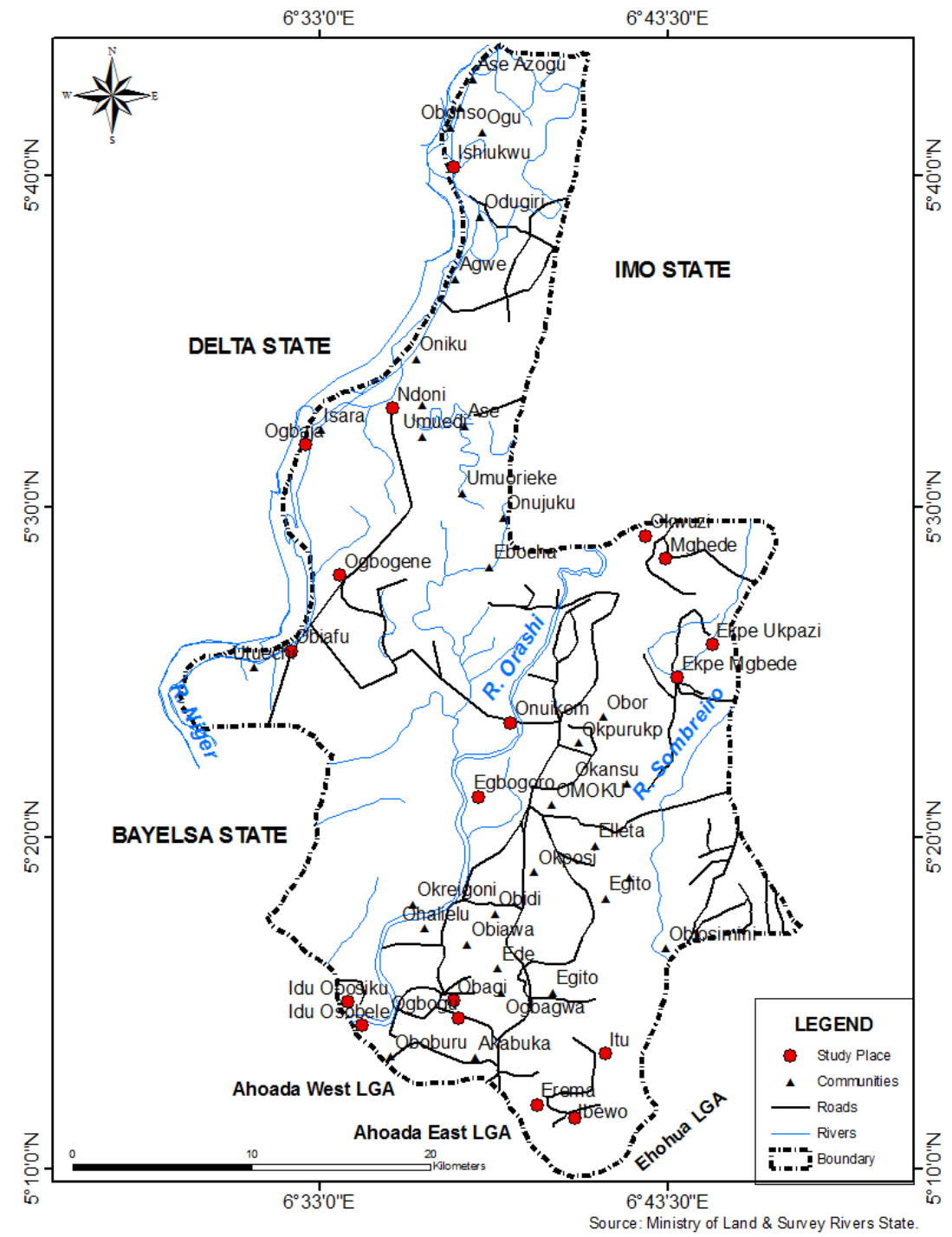

Figure2. ONELGA Showing the Different Communities 
Role of Governmental and Non-Governmental Agencies towards Disaster Risk Reduction in Rivers State, Nigeria

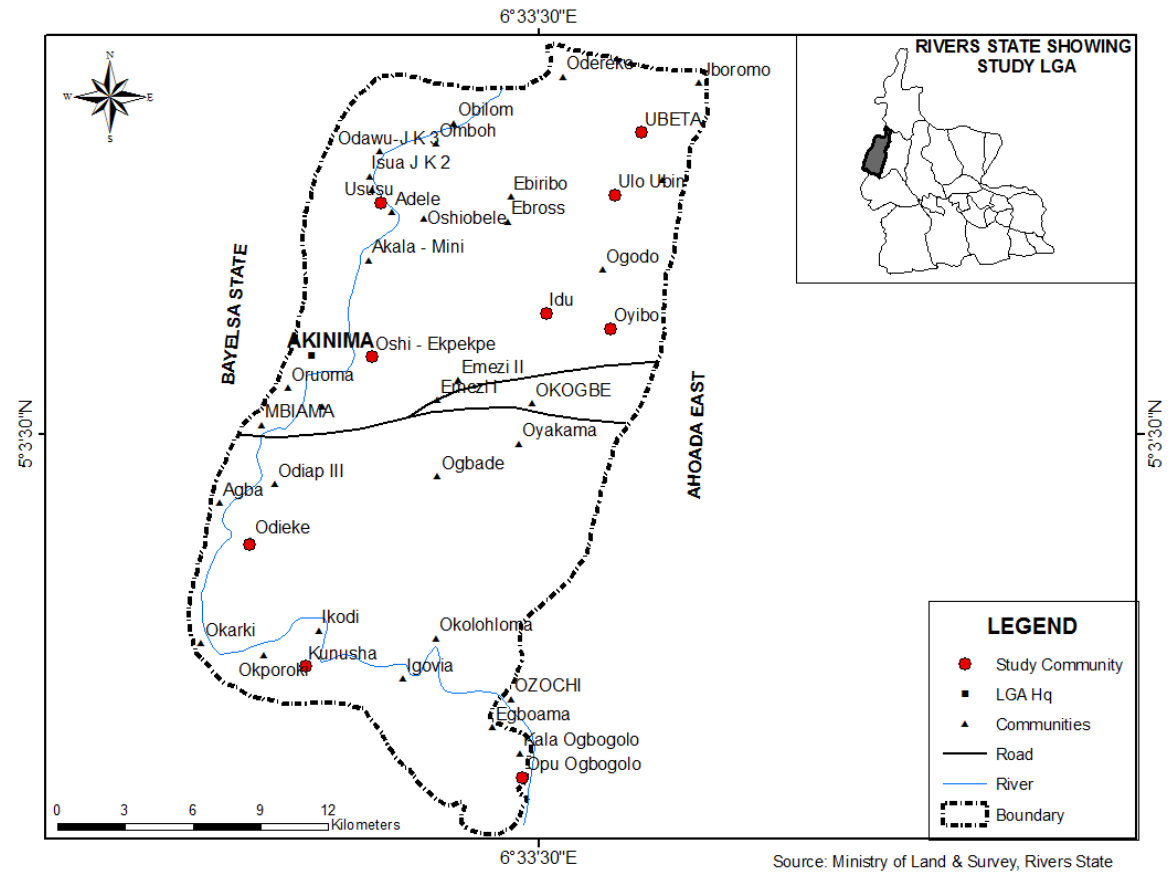

Figure3. AWELGA Showing the Different Communities

\section{RESUlts AND Discussion}

Table2. Administration and Retrieval of Questionnaire

\begin{tabular}{|l|l|l|l|l|}
\hline Zones & Quantity Served & Percentage Served & Quantity Retrieved & Percentage Retrieved \\
\hline Epkeye & 115 & 16.08 & 102 & 14.27 \\
\hline Engenni & 57 & 7.97 & 47 & 6.57 \\
\hline Ogba & 226 & 31.6 & 189 & 26.43 \\
\hline Egbema & 214 & 29.93 & 144 & 20.13 \\
\hline Ndoni & 103 & 14.41 & 92 & 12.87 \\
\hline Total & 715 & 100 & 574 & 80.27 \\
\hline
\end{tabular}

Source. Authors Analysis, 2018

Table 2 above shows the number of questionnaires distributed in both LGAs. The distribution of questionnaire was carried out based on the political zones in each LGA. The distribution in Ahoada West which comprises of 2 political zones is as follows: In Ekpeye, 115questionnaires was distributed and only 102 was retrieved; in Engenni, 57 questionnaires was distributed and only 47 was retrieved. ONELGA on the other hand comprises of three political zones namely: Ogba (226 questionnaires were distributed and only 189 was retrieved), Egbema (214 questionnaires were distributed and only 144 was retrieved), and Ndoni (103 questionnaire swere distributed and only 92 was retrieved).

Table3. Age and Sex Structure of Respondents

\begin{tabular}{|c|c|c|c|c|c|c|}
\hline Age & \multicolumn{6}{|c|}{ Sex } \\
\hline & Male & $\%$ & Female & $\%$ & Total & \% Total \\
\hline$<18$ & 17 & 4.71 & 13 & 6.10 & 30 & 5.23 \\
\hline $18-30$ & 90 & 24.93 & 64 & 30.05 & 154 & 26.83 \\
\hline $31-45$ & 139 & 38.51 & 56 & 26.29 & 195 & 33.97 \\
\hline $46-60$ & 76 & 2 L05 & 58 & 27.23 & 134 & 23.35 \\
\hline$>60$ & 39 & 10.80 & 22 & 10.33 & 61 & 10.62 \\
\hline Total & 361 & 100 & 213 & 100 & 574 & 100 \\
\hline
\end{tabular}

Source. Authors Analysis, 2018

Table 3 above shows that 361 respondents representing $62.89 \%$ are male while 213 respondents are female representing 37.11\%. It further shows that the age bracket 31-35 has the highest respondent of $33.97 \%$. This is indicative of the reliability of the data collected because the age group is matured and responsible. 
Role of Governmental and Non-Governmental Agencies towards Disaster Risk Reduction in Rivers State, Nigeria

Table4. Major Income and Education of Respondents

\begin{tabular}{|c|c|c|c|c|c|}
\hline Monthly Income (N) & Frequency & $\%$ & Education & Frequency & $\%$ \\
\hline$<10,000$ & 229 & 39.90 & No education & 56 & 976 \\
\hline $10,001-20,000$ & 96 & 16.72 & Non-Formal & 51 & 8.89 \\
\hline $20,001-30,000$ & 88 & 15.33 & Primary & 243 & 42.33 \\
\hline $30,001-40,000$ & 74 & 12.89 & Secondary & 104 & 18.12 \\
\hline $40,001-50,000$ & 53 & 9.24 & Tertiary 1 (ND, NCE \& HND) & 22 & 3.83 \\
\hline$>50,000$ & 34 & 5.92 & Tertiary 11 (PGD BSc, MSc \& PhD) & 574 & 100 \\
\hline Total & 574 & 100 & & &
\end{tabular}

Source. Authors Analysis, 2018

Table 4 clearly indicates thatabout $39.9 \%$ of the respondent are living below the poverty line as well as the Federal Governmentminimum wage of $18,000.00$ (Eighteen Thousand Naira Only) per month even though a new minimum wage bill pegging minimum wage in Nigeria at $\$ 30,000$ (Thirty Thousand Naira) has been appropriated but not implemented. It is shown that very few of the respondents earn above $\$ 50,000.00$ (Fifty Thousand Naira Only). The implication of these is that since they live below poverty, they will definitely be prone to disaster and development might be minimal.

In terms of education, table 4 reveals that secondary school leavers form bulk of the educational level of the respondent with about $42.33 \%$. This is followed by tertiary 1 with a frequency of 104 representing $18.12 \%$ and the primary school educational level at $17.07 \%$. Tertiary 11 accounts for $3.83 \%$, which is the lowest level of education of respondents in the study area. The implication of these is that the people will be least aware of the impact of disaster and its effect on development.

The table below highlights the most reoccurring disasters in both LGAs focusing on the communities where these disasters occurs.

Table5. Most Prevalent Disaster in AWELGA

\begin{tabular}{|l|l|l|l|l|l|}
\hline No & Communities Coveredin AWELGA & Total Respondents & Oil Spillage & Flooding & Others \\
\hline 1 & Idu-Ekpeye & 24 & 4 & 15 & 5 \\
\hline 2 & Oyigbo & 19 & 2 & 8 & 9 \\
\hline 3 & Ubeta & 20 & 6 & 10 & 4 \\
\hline 4 & Ulo & 12 & 1 & 7 & 4 \\
\hline 5 & Odieke & 10 & 0 & 6 & 4 \\
\hline 6 & Ogbologbolo & 17 & 3 & 5 & 9 \\
\hline 7 & Oshi & 6 & 1 & 4 & 1 \\
\hline 8 & Betterland & 4 & 0 & 0 & 4 \\
\hline 9 & UsusuJkl & 28 & 1 & 5 & 22 \\
\hline 10 & Kanusha & 9 & 1 & 0 & 8 \\
\hline & TOTAL & 149 & 19 & 60 & 70 \\
\hline
\end{tabular}

Source. Authors Analysis, 2018

Table 5 above show individuals residing in AWELGA opinion on the most prevalent disasters. Out of the 149 persons under study in 10 communities, opinions varied as follows: oil spillage (49 persons), flooding, (60persons), others (70 persons). The implication of this result is that 'others' category which include communal clashes, cultism, chieftaincy disputes, etc,are the most prevalent disasters in AWELGA

Table6. Most Prevalent Disaster by Respondents in ONELGA

\begin{tabular}{|l|l|l|l|l|l|}
\hline NO & Communities Covered & Total Respondents & Oil Spillage & Flooding & Others \\
\hline 1 & Obrikom & 32 & 22 & 8 & 2 \\
\hline 2 & Erema & 48 & 23 & 15 & 10 \\
\hline 3 & Ibewa & 12 & 6 & 4 & 2 \\
\hline 4 & Idu-Ogba & 20 & 7 & 12 & 1 \\
\hline 5 & Obagi & 23 & 15 & 3 & 5 \\
\hline 6 & Ogbogu & 43 & 22 & 15 & 6 \\
\hline 7 & Egbegboro & 7 & 4 & 2 & 1 \\
\hline
\end{tabular}


Role of Governmental and Non-Governmental Agencies towards Disaster Risk Reduction in Rivers State, Nigeria

\begin{tabular}{|c|c|c|c|c|c|}
\hline 8 & Itu & 4 & 2 & 1 & 1 \\
\hline 9 & Agah & 41 & 23 & 9 & 9 \\
\hline 10 & Ebocha & 20 & 7 & 8 & 5 \\
\hline 11 & Mgbede & 27 & 12 & 7 & 8 \\
\hline 12 & Okwuzi & 18 & 8 & 3 & 6 \\
\hline 13 & UgadaUkwu & 33 & 26 & 4 & 3 \\
\hline 14 & EkpeMgbede & 5 & 3 & 1 & 1 \\
\hline 15 & Ndoni & 38 & 4 & 30 & 4 \\
\hline 16 & Isukwa & 6 & 3 & 2 & 1 \\
\hline 17 & AbadaUkwu & 6 & 3 & 2 & 1 \\
\hline 18 & Ogbogene & 18 & 4 & 10 & 4 \\
\hline 19 & Obiafu & 14 & 12 & 2 & 0 \\
\hline \multirow[t]{2}{*}{20} & Utu & 10 & 3 & 4 & 3 \\
\hline & TOTAL & 425 & 209 & 142 & 74 \\
\hline
\end{tabular}

Source. Authors Analysis, 2018

Table 6 above show respondents' opinion on the most prevalent disaster in ONELGA which comprises 20 communities that covers the study location.Opinion from respondents on the most prevalent disasters reveals that out of the 425 persons under study, 209 persons implicated oil spillage, 142 persons reported flooding while 74 persons are of the opinion that 'others' category are the most prevalent disaster in ONELGA. This result shows that Oil Spillage is the most prevalent disaster in ONELGA since most respondent's opinion was based on that.

Table7. The Effect of Disaster Risk Reduction Activities on Development in AWELGA

\begin{tabular}{|l|l|l|l|l|}
\hline Question for agencies & Yes & Partially & No & Total \\
\hline $\begin{array}{l}\text { Fromyour observation, has your organization response to } \\
\text { disaster brought about meaningful development? }\end{array}$ & $11(55 \%)$ & $8(40 \%)$ & $1(5 \%)$ & $20(100 \%)$ \\
\hline
\end{tabular}

Source. Authors Analysis, 2018

Table8. DRR has Brought About Meaningful Development In AWELGA

\begin{tabular}{|c|c|c|c|c|c|}
\hline No & Zones & Total Respondent & YES & PARTIALLY & NO \\
\hline 1 & Ekpeye & 102 & 57 & 40 & 5 \\
\hline 2 & Engenni & 47 & 23 & 22 & 2 \\
\hline & TOTAl & 149 & 80 & 62 & 7 \\
\hline
\end{tabular}

Source. Authors Analysis, 2018

Table 7 above reveal in the first column agencies' opinion on their response to disaster; if it has brought about development in AWELGA.Results show that $55 \%$ officials of the agencies involved in DRR ticked Yes, $40 \%$ ticked partially and just 5\% ticked No.

While individuals residing in the communities under study based their opinion on the role of DRR in meaningful development as seen in table 8 as follows: out of 149 respondent, 80 persons ticked Yes, 62 persons ticked Partially and 7 persons ticked No. The analyzed result clearly shows that majority of the officials of Agencies involved in DRR believed that their Agencies' effort has brought sustainable development while majority of respondents living the communities where DRR activities are being carried out also believe that DRR has brought about sustainable development.

The next table reveals Agencies' response based on the effect of their activities on development the ONELGA.

Table9. The Effect of Disaster Risk Reduction Activities on Development in ONELGA

\begin{tabular}{|l|l|l|l|l|}
\hline Question for Agencies & Yes & Partially & No & Total \\
\hline $\begin{array}{l}\text { From your observation has your organization } \\
\text { response to disaster brought about meaningful } \\
\text { development? }\end{array}$ & $15(75 \%)$ & $5(25 \%)$ & $0(0 \%)$ & $20(100 \%)$ \\
\hline
\end{tabular}

Source. Authors Analysis, 2018 
Role of Governmental and Non-Governmental Agencies towards Disaster Risk Reduction in Rivers State, Nigeria

Table10. DRR Has Brought About Meaningful Development In ONELGA

\begin{tabular}{|l|l|l|l|l|l|}
\hline No & Zones & Total Respondent & YES & PARTIALLY & NO \\
\hline 1 & Ogba & 189 & 99 & 60 & 30 \\
\hline 2 & Egbema & 144 & 65 & 44 & 35 \\
\hline 3 & Ndoni & 92 & 39 & 45 & 8 \\
\hline & TOTAL & 425 & 203 & 149 & 73 \\
\hline
\end{tabular}

Source. Authors Analysis, 2018

Table 9 entries above reveal in the first column Agencies' opinion on their response to disaster; if it has brought about development in ONELGA or not. The results show that $15(75 \%)$ officials of the Agencies involved in DRR ticked Yes, 5(25\%) ticked partially and Non ticked No. Table 10 on the hand, shows individuals residing in theseLGA's opinion as follows: out of 425 respondents, 203 persons ticked YES, 149 respondents ticked PARTIALLY and 73 persons ticked No.The analyzed result implies that majority of the Agencies involved in DRR believed that their Agencies' effort has brought sustainable development while majority of respondent living in the community where DRR activities are being carried out believes fully that DRR has brought about sustainable development.

The next table shows the respondents opinion on the factors behind Agencies' successes in DRR effort.

Table11. UnderlyingFactors Contributing to DRR Success in AWELGA?

\begin{tabular}{|l|l|l|l|l|}
\hline Question & Adequate Funding & $\begin{array}{l}\text { Partnership/Col } \\
\text { laboration }\end{array}$ & $\begin{array}{l}\text { Training and } \\
\text { Retraining of } \\
\text { staff }\end{array}$ & Total \\
\hline $\begin{array}{l}\text { In the years you have carried out disaster risk } \\
\text { reduction activities, what are the challenges or } \\
\text { underlying factors that have made you succeed }\end{array}$ & 6 & 10 & 4 & 20 \\
$(20 \%)$ & $(50 \%)$ & $\begin{array}{l}(100 \\
\%)\end{array}$ \\
\hline
\end{tabular}

Source. Authors Analysis, 2018

Table 11 above reveal in the first column agencies' opinion on challenges/success factors towards a successful DRR implementation in AWELGA. The result shows that 6(30\%) officials of the agencies involved in DRR ticked 'Adequate funding'.10(50\%) ticked 'Partnership/Collaboration' and 4(20\%) ticked 'Training/Retraining of staff as a key to its success in its DRR efforts.

Thus, with the analyzedresult, itis obvious that majority of the officers of Agencies involved in DRR believes that great success has been recorded due to certain factors which are listed above and in summary partnership/collaboration is the major stronghold behind the successes.

Table12. UnderlyingFactors Contributing to these DRR Successes in ONELGA?

\begin{tabular}{|c|c|c|c|c|}
\hline Questions & $\begin{array}{c}\text { Adequate } \\
\text { Funding }\end{array}$ & $\begin{array}{c}\text { Partnershi/ } \\
\text { Collaboration }\end{array}$ & $\begin{array}{c}\text { Training and } \\
\text { Retraining of staff }\end{array}$ & Total \\
\hline $\begin{array}{c}\text { In the years you have carried out disaster risk } \\
\text { reduction activities, what are the challenges or } \\
\text { underlying factors that have made you succeed }\end{array}$ & $7(35 \%)$ & $9(45 \%)$ & $4(20 \%)$ & $20(10$ \\
$0 \%)$ & & & & \\
\hline
\end{tabular}

Source. Authors' Analysis, 2014

Table 12 above clearly reveal in the first column Agencies' opinion on challenges/success factors towards a successful DRR implementation in ONELGA and the results shows that 7(35\%) officials of the agencies involved in DRR ticked 'Adequate Funding', 9(45\%) ticked 'Partnership/Collaboration' and 4(20\%) ticked 'Training/Retraining' of staff as a key to its success in its DRR efforts.

The above result clearly indicates that majority of the officers of Agencies involved in DRR believes that great success has been recorded due to certain factors which are listed above particularly'Partnership/Collaboration' which is the major factor behind the successes.

Table13. Opinion on Methodologies for Sustainable Development in both LGAs

\begin{tabular}{|l|l|l|l|l|l|l|}
\hline $\begin{array}{l}\mathrm{N} \\
\mathrm{o}\end{array}$ & $\begin{array}{l}\text { Name } \\
\text { Community }\end{array}$ & $\begin{array}{l}\text { Total } \\
\text { Respondent }\end{array}$ & $\begin{array}{l}\text { PROPER } \\
\text { FUNDING }\end{array}$ & $\begin{array}{l}\text { PARTNERSH } \\
\text { IP }\end{array}$ & $\begin{array}{l}\text { TRAININ } \\
\text { G }\end{array}$ & OTHER FACTORS \\
\hline 1 & Idu-Ekpeye & 24 & 15 & 2 & 2 & 5 \\
\hline 2 & Oyigbo & 19 & 9 & 2 & 4 & 4 \\
\hline 3 & Ubeta & 20 & 8 & 5 & 5 & 2 \\
\hline 4 & Ulo & 24 & 4 & 3 & 3 & 14 \\
\hline 5 & Odieke & 10 & 3 & 3 & 3 & 1 \\
\hline 6 & Ogbologbolo & 17 & 4 & 4 & 4 & 5 \\
\hline
\end{tabular}


Role of Governmental and Non-Governmental Agencies towards Disaster Risk Reduction in Rivers State, Nigeria

\begin{tabular}{|c|c|c|c|c|c|c|}
\hline 7 & Oshi & 6 & 2 & 4 & 0 & 0 \\
\hline 8 & Betterland & 4 & 4 & 0 & 0 & 0 \\
\hline 9 & UsusuJk 1 & 28 & 15 & 5 & 4 & 4 \\
\hline 10 & Kanusha & 9 & 5 & 2 & 2 & 0 \\
\hline 11 & Obrikom & 32 & 16 & 4 & 6 & 6 \\
\hline 12 & Erema & 48 & 19 & 11 & 4 & 14 \\
\hline 13 & Ibewa & 12 & 2 & 4 & 2 & 4 \\
\hline 14 & Iclu-Ogba & 20 & 9 & 5 & 3 & 3 \\
\hline 15 & Obagi & 23 & 10 & 9 & 0 & 4 \\
\hline 16 & Ogbogu & 43 & 22 & 14 & 4 & 3 \\
\hline 17 & Egbegboro & 7 & 2 & 2 & 2 & 1 \\
\hline 18 & Itu & 4 & 3 & 1 & 0 & 0 \\
\hline 19 & Agah & 41 & 23 & 7 & 5 & 6 \\
\hline 20 & Ebocha & 20 & 7 & 3 & 3 & 7 \\
\hline 21 & Mgbede & 27 & 20 & 4 & 0 & 3 \\
\hline 22 & Okwuzi & 18 & 9 & 7 & 2 & 0 \\
\hline 23 & UgadaUkwu & 33 & 20 & 4 & 4 & 5 \\
\hline 24 & EkpeMgbede & 5 & 3 & 2 & 0 & 0 \\
\hline 25 & Ndoni & 38 & 28 & 3 & 4 & 3 \\
\hline 26 & Isukwa & 6 & 2 & 2 & 0 & 2 \\
\hline 27 & AbadaUkwu & 6 & 6 & 0 & 0 & 0 \\
\hline 28 & Ogbogene & 18 & 12 & 2 & 4 & 0 \\
\hline 29 & Obiafu & 10 & 10 & 0 & 0 & 0 \\
\hline \multirow[t]{2}{*}{30} & Utu & 2 & 1 & 1 & 0 & 0 \\
\hline & Total & 574 & 293 & 115 & 70 & 96 \\
\hline
\end{tabular}

Source. Authors' Analysis, 2018

The entries on table 13 above reveal respondent's opinion on useful methodologies towards a successful DRR implementation in both LGAs. Results of the analysis shows that 293 persons ticked 'Proper Funding', 115 persons ticked 'Partnership/Collaboration', 70 persons ticked 'Training/Retraining' of staff and 96 ticked 'Other Factors' as responsible forthe success in DRR efforts. The analyzed result therefore implies that majority of respondents who reside in communities where DRR activities are been carried out believes that adequate funding would be a proper methodology in sustaining DRR activities.

\subsection{Testing of Research Hypothesis}

The research hypothesis was tested using the Spearman Rank Order Correlation and was analyzed using statistical package for social science (SPSS) version 20.

H01: The level of the role of Governmental and Non-Governmental Agencies in disaster risk reduction activities is not significantly associated with sustainable development.

Table14. Z-test Analysis - Level of the Role of Governmental and Non-Governmental Agencies in Disaster Risk Reduction Activities and Sustainable Development.

\begin{tabular}{|c|c|c|c|c|c|c|c|c|}
\hline Status & $\mathbf{N}$ & $\bar{x}$ & SD & Df & $\begin{array}{c}\text { Z- } \\
\text { cal }\end{array}$ & $\begin{array}{c}\text { Critical } \\
\text { value }\end{array}$ & $\begin{array}{c}\text { Levelsof } \\
\text { significance }\end{array}$ & Decision \\
\hline Level & 20 & 2.59 & 0.57 & 733 & 4.20 & 1.69 & 0.05 & $\mathrm{H}_{01}$ is rejected \\
(Significant)
\end{tabular}

Table 14 shows that the calculated z-value of 4.20 is greater than the critical z-value of 1.69 with 733 degree of freedom at 0.05 level of significance. Since the calculated z-value is greater than the critical $\mathrm{z}$-value, the null hypothesis is rejected. Therefore, the conclusion becomes: the level of the role of Governmental and Non-Governmental agencies in disaster risk reduction activities is significantly associated with sustainable development.

\section{CONCLUSION AND RECOMMENDATIONS}

From the investigation, it is clear that the most prevalent disaster in AWELGA is flooding while in ONELGA is Oil spillage. Majority of the respondent from the Agencies that carry out DRR activities and those residing in the communities where DRR is being carried out in both local government areas had their opinion that DRR activities have led to a remarkable sustainable development. In addition, majority of the respondent who are Officials of Agencies involved in DRR had their opinion that 
Role of Governmental and Non-Governmental Agencies towards Disaster Risk Reduction in Rivers State, Nigeria

adequate funding, partnership, training and retraining of staff are the principle factors that have led to the success of DRR activities carried out by both governmental and nongovernmental organization which have brought about sustainable development with adequate funding taking topmost priority.

Based on the findings of this study, it is recommended that officials of government and nongovernmentAgencies involved in Disaster Risk Reduction activities should be well trained in line with global standard. In addition, the administration of Disaster Risk Reduction policies should be better supported financially and otherwise for effective monitoring and enforcement of DRR laws. This is based on the results that shows that majority of the respondent agreed that adequate training will lead to more effectiveness in their responsibilities

DRR policies should embrace totally, inputs from indigenous people in terms of participation and or consultation to help in the implementation process especially in the area of monitoring for compliance. Policies must also take account the real indigenous socio economic, and cultural characteristics of the people. Community or public awareness should be highly encouraged, the people should be educated or enlightened through journals, workshops, community town hall meetings and enlightenment campaign as a meansof information by the government and nongovernmentalAgencies to disaster prone communities

There should be a more robust and all-inclusive partnership and collaboration with other stakeholders involved in DRR activities across the globe in order to ensure compliance with global best practices in the LGAs.

\section{REFERENCES}

[1] Annual Disaster Statistical Review (2012); An Annual Report of the Disaster Prevalence in South America (www.em-dat.net)

[2] Boudreau, R. (2009); Implementing Disaster Policy, Washington DC; Congressional Quarterly Press

[3] DFID (2006); Division of Sustainable Development, UK

[4] Donovan, G. and Casey, D. (1998) Soil Fertility Management in Sub-Saharan Africa. Technical Paper, Wood Bank, Washington DC

[5] ISDR (2004) Disaster Reduction in Africa: ISDR Reforms, Issue 4.

[6] Kreimor, P.\&Munasinghe, M.(1991); "Disaster Project", Innovator. Vol. III No. 2, Bans: A monthly Newsletter of Skills Development Initiative, February

[7] Munasinghe, M. (2016); Disaster Prevention for Sustainable Development. Journal of Environmental Degradation in Europe National Bureau of Statistics (2017)

[8] Batchelor, S; Smith, J and Fleming, J. (2014) Decentralisation in Sub-Saharan Africa: Prevalence, Scope and Challenges. Working Paper, Low Carbon Energy for Development Network

[9] National Population Commission, NPC (2006) Population Distribution by Sex, State, LGA's, Senatorial District; 2006 Priority Tables, 3.

[10] Twiggs, J. (2007) Characteristics of a Disaster-resilient Community; A Guidance Note. Benfield UCL Hazard Research Centre, London

[11] UNEP (2002) United Nations Environment Programme Annual Evaluation Report, Geneva

[12] UNDP (2012) Reducing Disaster Risk, A Challenge for Development

[13] UN/ISDR (2002) Words into Action; AGuide for Implementing the Hyogo Framework, Geneva

[14] UN/ISDR (2009) Review of Action; AGuide for Implementing the Hyogo Framework. Geneva

[15] UN/ISDR \& UNDP (2003); Disaster Management; A Development Concern in Africa, Geneva

[16] World Food Programme (2003) Annual Report; Rome, Italy

Citation: Collins H. Wizor (Ph.D), Cookey, Aloma Tammy (Ph.D), "Role of Governmental and NonGovernmental Agencies Towards Disaster Risk Reduction in Rivers State, Nigeria", International Journal of Research in Environmental Science (IJRES), vol. 5, no. 3, pp. 42-63, 2019. Available: DOI: http://dx.doi.org/10.20431/2454-9444.0503007

Copyright: (C) 2019 Authors. This is an open-access article distributed under the terms of the Creative Commons Attribution License, which permits unrestricted use, distribution, and reproduction in any medium, provided the original author and source are credited. 